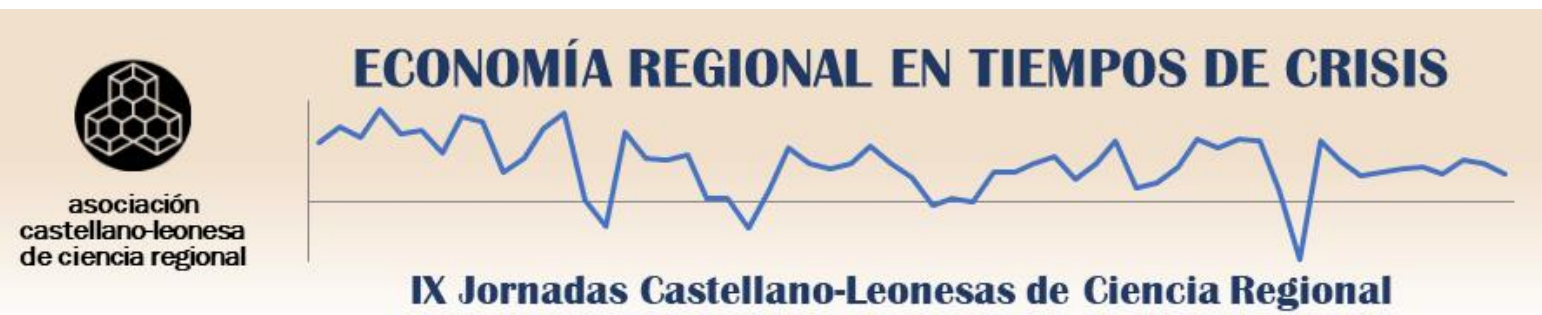

\title{
HIGHER EDUCATION, REGIONAL GROWTH AND COHESION: INSIGHTS FROM THE SPANISH CASE
}

\author{
JUAN FRANCISCO CANAL DOMÍNGUEZ \\ Universidad de Oviedo. Departamento de Economía
}

jfcanal@uniovi.es

\section{Resumen}

Este artículo pretende analizar la relación entre el crecimiento económico regional y el desarrollo de la educación superior. Para ello se abordará desde una perspectiva macroeconómica, utilizando un panel de datos relativos al conjunto de las comunidades autónomas españolas para el periodo comprendido entre 1985 y 2016. El crecimiento económico regional se mide en términos de Producto Interior Bruto per cápita, mientras que el crecimiento de la educación superior se mide en términos de un indicador alternativo al utilizado tradicionalmente en la literatura: alumnos matriculados en cada año académico. El principal resultado es la estimación de un efecto positivo de la educación superior en el crecimiento regional. Además, dado que este efecto es más intenso en las regiones menos desarrolladas económicamente, se puede concluir que la educación superior juega un efecto positivo en la cohesión económica y social entre regiones, reduciendo las diferencias económicas y de bienestar. Por otra parte, la reducida movilidad interna de la mano de obra en España tiene su reflejo en un efecto no significativo entre regiones. Finalmente, el análisis de los efectos composición se muestra relevantes dado que se pueden observar efectos de distinta intensidad en función del campo de conocimiento en el que se ha formado el trabajador.

Palabras clave: Crecimiento económico, regiones, educación superior, cohesión económica

Área temática Economía regional

\begin{abstract}
This paper is aimed at studying the link between the regional economic growth and higher education development in a macroeconomic regression for a panel of Spanish regions between 1985 and 2016. The regional economic growth is measured as GDP growth per capita, whereas higher education development is calculated by means of an alternative indicator to the ones used in the traditional literature: the growth rate of the total number of students enrolled in each academic year. We find that higher education growth has a positive impact on the regional macroeconomic growth. As this effect is more intense in less wealthy regions, we may conclude that higher education plays a positive role in the regional economic and social cohesion, when narrowing the economic well-being gap among regions. On the other hand, the reduced internal mobility of labour force in Spain is reflected in the existence of some little intense spillover neighbouring effects. Finally, composition effect analysis becomes relevant as we can observe many different effects in the field of knowledge.
\end{abstract}

Key words: Economic growth, regional, higher education, economic cohesion

Thematic Area: Regional economics 


\section{INTRODUCTION}

There is a general consensus that education improves individuals' productivity by increasing their human capital stock and therefore contributes to growth (Hanushek and Wößmann, 2010). As Aghion et al. (2006) pointed out, high productivity and innovation make a relatively more intensive use of skilled labour, so that the analysis of the impact of education on economic growth becomes particularly relevant when dealing with higher education.

There is extensive literature that analyses the link between human capital and economic growth from a macroeconomic perspective. These papers mainly used national data while, however, the regional scope provides a more appropriate analysis scenario than the international one. On the one hand, using large international datasets incorrectly imposes a single coefficient and thus equal returns on schooling among different countries. On the other hand, the regional analysis allows controlling for the heterogeneity problem by focusing on a more homogeneous dataset rather than on an international sample (Di Liberto, 2008; Hanushek, 2013)

Nevertheless, the majority of papers analysing the link between higher education and economic development at regional level show a microeconomic approach assessing; for example, the effect of higher education on business activities, entrepreneurship, technological innovation, existing know-how transfer or human capital stock. Drucker and Goldstein research (2007) includes an extensive summary of empiric papers for the USA, Canada and the EU, and offers a review of the studies from a methodological perspective. More recently, Bonaccorsi et al. (2019) present a wide updated survey of existent literature classified according to the pathways through which higher education institutions impact on the economy: generation of human capital, research activities, start-up design, attractiveness for foreign investment, and highly added-value procurement.

However, based micro-analyses do not allow assessing the effect of higher education on economic growth accurately. According to Lucas (1988), public returns to education exceed private returns, often assuming that high average levels of human capital along the economy increase any given worker's productivity. On the other hand, Di Liberto (2008) considers that differences in human capital endowments and their rates of investment have long been recognised as an important element in explaining observed GDP gaps. However, there are a few studies that analyse the effect of education on regional development from a macroeconomic point of view, and only Valero and Van Reenen (2019) specifically analyse the effect of higher education. They use information of 15,000 universities in about 1,500 regions across 78 countries between 1950 and 2010 to reach the conclusion that a 10\% increase in the number of universities is associated with over $0.4 \%$ higher GDP per capita in a region. Their paper presents three main weaknesses: first, as they use the number of universities as an indicator of higher education development level, they do not take into account the quantitative effect (the number of students per university is not stated); second, also missing some observations as many regions which either have 0 universities or do not show any variation in its number during a great part of the analysed period (the median growth rate of the number of universities is zero); third, using information of countries around the world makes it more complicated to define what a region is like, so that for example, they take California (USA), whose GDP doubles that of Spain, the same as the province of Lugo (NUTS3, and located in Spain), which has not got any universities, and represents $0.7 \%$ of Spanish GDP. Finally, using large international data sets incorrectly imposes a single coefficient among regions of different countries.

Therefore, this research is aimed at providing empirical evidence to know more about the impact of higher education on regional economic growth using a macroeconomic regression for a panel of Spanish regions. For such purpose, GDP per capita shall be used as a macroeconomic indicator, whereas higher education relevance will be measured in terms of the total number of enrolments each year (university students stock). Besides, we will try to control for the effect of wealth inequality among regions, the spillover effect among regions, and the composition effect coming from the different fields of knowledge individuals may choose. For such purpose, we will use economic data of Spanish Autonomous Regions (NUTS2 according to Eurostat terminology) covering the period 1985-2016. The available information represents a panel data to be estimated by each region's fixed effects. 
The paper is structured as follows. The second section offers information about the database. Section three contains the empirical framework, whereas section four offers estimate results. Finally, section five gathers the most relevant conclusions.

\section{DATA SOURCES.}

The analysed period began in 1985 and finished in 2016, which was the last year providing the necessary information to generate this research. The year 1985 was chosen for two reasons; in economic terms, year 1985 meant the beginning of the current Spanish economic development, as it was the last transitional year before joining the EU in 1986. In terms of educative policy, 1985 came immediately after the most important university educational reform in the history of Spain (LRU of 1983), which built the foundations of the current Spanish university system.

Data related to the university system have been obtained from information provided by the Ministry of Universities, except for data related to Ceuta and Melilla as they do not have their own university and are very small territories ${ }^{1}$.

RegData database, generated by De la Fuente (2017), is the source of economic and population-related information, and is posted on its website by FEDEA (www.fedea.net). A constant price-bass GDP series is built out of this database for year 2010 at NUTS2 level (Autonomous Region) using the Spanish Regional Accounts (CRE), and a series of population living in Autonomous Regions using data from the Economically Active Population Survey (EPA). Both CRE and EPA are generated by National Statistics Institute (www.ine.es).

The information obtained allows the construction of a data panel for the period 1985-2016.

\section{EMPIRICAL FRAMEWORK}

\subsection{BASIC MODEL}

In econometric terms, the basic model is:

$$
\Delta \ln (G D P / L)_{i . t}=\alpha_{1} \Delta \ln (e s)_{i . t}+\varepsilon_{i . t}
$$

where $i$ refers to the Autonomous Region, $\Delta \ln (G D P / L)_{i . t}$ in the interannual variation rate of the GDP per capita logarithm in that year $t ; \Delta \ln (e s)_{i . t}$ is the interannual variation rate of the enrolment logarithm, and $\varepsilon$ is the error term. Given that both the dependent and independent variables are measured by the variation rates of the values taken in the logarithm, the estimated coefficient for the es variable is understood as an elasticity.

GDP per capita has been used as an economic growth indicator given the generalized agreement of its convenience: GDP per capita is an important indicator of economic performance and a useful unit to make comparisons of average living standards and economic well-being. As any other macroeconomic indicator, it has its own limits, for example the fact that it does not take into account income distribution in an economic area.

The total number of enrolments, that is, university students stock, has been used as a higher education level indicator for each year and for each autonomous region. Therefore, enrolment growth rate measures new students joining tertiary education each year after discounting exits (either because students obtain the degrees or because they drop out their studies). The analysis of the available official data and of prior research allows defining the stable dropout rates as the working hypothesis for the analysed period. Then, it means that the interannual growth rates are systematically corrected by the dropout effect. That is, if a given percentage of students drop every year, then, in a year $t$, when correcting dropouts between $t$ and $t-1$ shall effectively include the future dropout of students enrolled in year $t$.

The use of the number of enrolments as the higher education level indicator is considered as an advantage that allows quantitatively assessing a region's university offer $^{2}$, which could not be

\footnotetext{
${ }^{1}$ A specific case is that of students enrolled in UNED, Spanish Open University, located in the Autonomous Region of Madrid, and whose students are found all around Spain. Given that there is no available information related to their location for the analysed period, we have proceeded to distribute UNED students among the Autonomous Regions according to their population share weight.
} 
done when using the number of universities instead, as Valero and Van Reenen (2019) do. The best measurements would be in terms of the education output, but due to the difficulties in obtaining such measurements, input measurements are normally used (Sianesi and Van Reenen 2003). Following De Meulemeestert and Rochat (1995), with a variable measuring a stock of graduates it would be difficult to disentangle the contribution of formal education from the experience acquired on the job. Likewise, to explain total economic output based on public expenditure on higher education might be misleading by confounding public inputs with public outputs.

Finally, fixed-effect estimation techniques have been used, which according to Sianesi and Van Reenen (2003), prevent the analysis of the impact on growth of variables that do not change much over time. Besides, Gennaoili et al. (2013) consider that the effects of education and institutions are difficult to disentangle across regions (both variables are endogenous and the potential instruments for them are correlated), however by using region fixed effects we avoid identification problems caused by unobserved region-specific factors.

According to Sianesi and Van Reenen (2003), Gennaoili et al. (2014), and Valero and Van Reenen (2019), as income grows, educational standards rise, but we cannot be confident that economic growth is caused by higher educational standards. There are in fact reverse causality problems with education. When longitudinal datasets are available, one possibility is to use lags of the endogenous variables as instruments.

Considering the foregoing, the model to estimate would be:

$$
\Delta \ln (G D P / L)_{i . t}=\alpha_{1} \Delta \ln (e s)_{i . t-n}+\varepsilon_{i . t}
$$

where $i$ refers to the Autonomous Region, $\Delta \ln (G D P / L)_{i . t}$ is the interannual variation rate of GDP per capita algorithm for year $t, \Delta \ln (e s)_{i . t-n}$ is the interannual variation rate of the enrolment logarithm for the period $t-n$, and $\varepsilon$ is the error.

Anyway, it seems reasonable to introduce lagged enrolment variation rates in the model: today's economic growth is the result of an increase in previous enrolments, as some time is needed to finish university education and obtain an employment. Therefore, the question is how long the variable must be lagged. Regardless the country analysed, there is no ideal number of years. Two factors must be considered in case of university education in Spain:

$1^{0}$ The length of different kinds of degree granted by Spanish universities. During the period analysed (1985-2016), there were different degrees living together, which lasted for different periods: Diploma (3 years), Degrees (3 or 4 years) and Bachelor Degree (5 or 6 years).This means that the variable that gathers enrolments should be entered in the model to estimate 6years lag at least ${ }^{3}$.

$2^{\circ}$ The time graduates take to find a job in Spain. Empiric evidence shows that Spanish graduates, compared to their European peers, need more time to find a job and develop their professional careers (Salas 2007; Kivinen and Nurmi 2014; Canal and Rodríguez 2019). Therefore, there would be a greater lag when transferring the impact of increasing enrolments on the economic growth.

Therefore, if we consider the length of university degrees and the time it takes Spanish graduates to join the labour market, we may conclude that the stated lag for the variable gathering the number of enrolled students should be longer than 6 years. Following Valero and Van Reenen (2019) criterion, since tertiary education impact could take place over a longer period of time, we consider 8 years to be a conservative approach. Graph 1 plots the average

\footnotetext{
${ }^{2}$ It has not been possible to control higher education quality because information for all universities and all academic years is not available.

${ }^{3}$ According the figures stated by the Ministry of Universities, the number of students enrolled as new students of the new Bologna Plan was 1.3\% of the total number of enrolled students for the first year of the Bologna Plan (2008-2009 Academic Year). Given that entering the effect of the number of enrolled students in estimates is lagged 8 years, the last year from which data are taken is year 2008. Given the residual relevance of the number of enrolled students in the Bologna Plan that year, no reference to the effect education changes caused by this Plan might have, has been included.
} 
annual growth in regional GDP per capita (on the $y$-axis) on the average annual growth of enrolments (on the x-axis) with an 8-year lag, over the whole time period. The graph seems to show a positive relation between both growth rates, as it can be understood from the increasing slope of the trend line (0.19). In any case, the causal relationship must be determined based on the econometric estimate outcomes.

FIGURE 1. Growth rates. One observation by Autonomous Region. 1985-2016

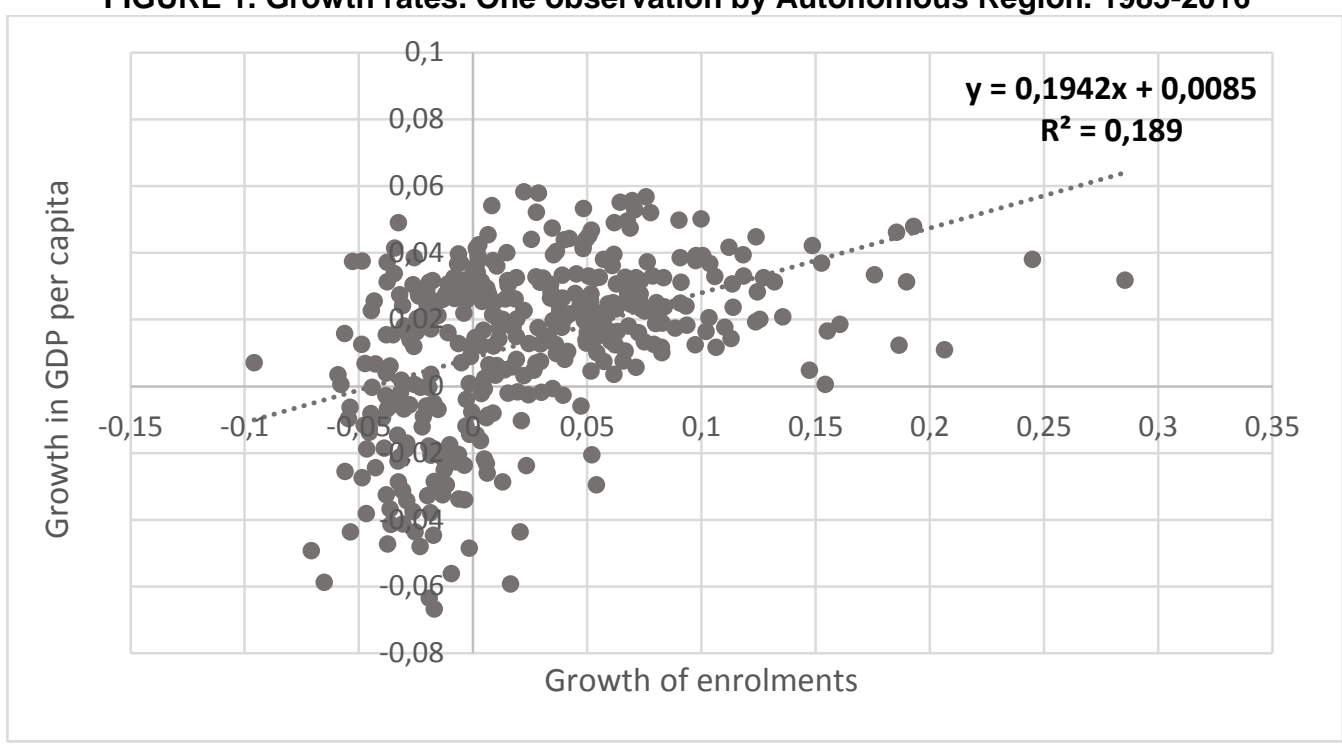

Source: Regdata and National Statistics Institute

On the other hand, it must be taken into account that each Autonomous Region has different social and economic features that may influence their decision of enrolling at the University and therefore, the economic growth. For this reason, an extended model is proposed to include a series of control variables for each Autonomous Region:

$$
\Delta \ln (G D P / L)_{i . t}=\alpha_{1} \Delta \ln (e s)_{i . t-n}+\alpha_{2} X_{i, t-n}+\alpha_{3} \Delta \ln Z_{i, t-n}+\alpha_{3} \Delta \operatorname{lnu}_{i . t}+\varepsilon_{i . t}
$$

here i refers to the Autonomous Region, $\Delta \ln (G D P / L)_{i . t}$ is the interannual variation rate of the GDP per capita logarithm for year $t, \Delta \ln (e s)_{i . t-n}$ is the interannual variation rate of the enrolment logarithm for the period $t-n ; X_{i, t-n}$ will be a vector of observable variables that characterize the social and economic situation of the Autonomous Regions during the enrolment period $t-n$ (population, GDP per capita, and percentage of population with university studies in order to calculate human capital stock level); $\Delta \ln Z_{i, t-n}$ a vector of variables that gather the cycle and demographic trend during the period $t-n$ (interannual variation rate of unemployment logarithm and interannual variation rate of population logarithm); $\Delta \ln u_{i . t}$ is the interannual variation rate of unemployment logarithm at a moment $t$, which is meant to reflect the cycle effect for the period $t$; being $\varepsilon$ the error.

Five models will be estimated based on this econometric specification. Starting with a basic model where the only independent variable is enrolments during the period $t-n$ (Model 1 ), the introduction of the following control variables shall allow assessing the explanatory capacity that university education has on the economic growth. Therefore, Model 2 includes the variables that characterize the social and economic features of the Autonomous Regions for the period $t-n$; Model 3 adds the variable that approximate human capital level at the Autonomous Region for the period $t-n$; Model 4 includes those variables that control for the economic cycle for the period $t-n$ and in the moment when the growth of GDP per capita is assessed $(t)$. Finally, Model 5 adds the variable controlling for demographic trends for the period $t-n$.

\subsection{SAMPLE CHECKS: HETEROGENEITY}

In spite of the included controls for different socio-economic features of Autonomous Regions, one single equation estimate establishes the same enrolment effect for all Autonomous Regions. However, this coefficient is expected to differ among regions, given the existence of 
socio-economic differences among them. For example, Di Liberto (2008) thinks that it is also convenient to carry out an estimate of the effects of education in Italy by gathering regions into two groups: North-Centre (wealthy regions) vs South (poor regions).

For such purpose, Autonomous Regions have been divided into three groups depending on the average GDP per capita for the whole analysed period: Group 1 includes the traditionally wealthiest regions (Madrid, Cataluña, País Vasco, Navarra); Group 2 includes those Regions with a GDP per capital higher than the national average but lower than those in Group 1 (Aragón, Rioja, Baleares); and Group 3 with the rest of Autonomous Regions (Cantabria, Valencia, Asturias, Castilla y León, Castilla La Mancha, Canarias, Murcia, Galicia, Andalucía, Extremadura). The model to estimate now would be:

$$
\Delta \ln (G D P / L)_{i, j, t}=\alpha_{1} \Delta \ln (e s)_{i, j, t-n}+\alpha_{2} X_{i, j, t-n}+\alpha_{3} \Delta \ln Z_{i, j, t-n}+\alpha_{3} \Delta \operatorname{lnu}_{i, j, t}+\varepsilon_{i, j, t}
$$

where $j=1,2,3$ refers to the group Autonomous Region $i$ belongs to.

\subsection{SAMPLE CHECKS: SPILLOVER EFFECTS}

Given that workers want to return on their investment in higher education, some of them are expected to move outside the Autonomous Region where their university is located. In the Spanish case, a great amount of research identifies the existence of geographical mobility constrains for the labour force, which leads to little mobility within the national territory. This low mobility also covers short distances. There is sufficient literature to confirm this migratory pattern during the last quarter of the 20th Century (see Bentolila 2001; Ródenas and Martí 2005; Alcaide 2007). The turn of the century did not seem to have meant a change in this behaviour according to official statistics. Given that job seeking is normally the main reason for domestic migrations, it was decided to use the official figures provided by the Servicio Público de Empleo Estatal (SEPE) [Public Service for Employment Search], that gather all employment contracts done in Spain since the beginning of the current century. If we consider 2016 figures as an example (last year in this paper's analysis), exit rates of workers from their Autonomous Region (workers moving to other Autonomous Regions to start a new job, out of the total of workers remaining working in the Autonomous Region plus those who leave), was 9\%, whereas that of workers holding a university degree was not that different $(10.8 \%)$ and almost equal to that of workers with no studies (10.7\%). On the other hand, the "2014 Survey on Labour Insertion of University graduates" drafted by INE, analysed the transition to the labour market of those Spanish university graduates who enrolled the academic year 2009-10. In this case, data indicate that $14 \%$ of university graduates left the autonomous region where they studied in order to work in another Autonomous Region (Pérez 2018).

The question is, do Spanish workers move to any Autonomous Region in order to work? SEPE (2016) stated that $75 \%$ of workers moved out to their neighbouring autonomous region, or to Madrid if this was not among nearby regions. This seems to indicate that the two first decades of 21st century are copying the pattern observed at the end of 20th century by Ródenas and Martí (2005), who concluded that any migration movement beyond the limit of a province (NUTS3) was to nearby places mainly located in neighbouring provinces, regardless their belonging to the same Autonomous Region (NUTS2) or not. SEPE does not provide information about the Autonomous Regions of destination in relation to workers holding university degrees. However, it is reasonable to suppose that their migratory behaviour should follow the same trend observed in workers as a whole ${ }^{4}$.

Taking all this into account, an estimate of spillover effects is proposed, which will be based on an annual exit rate of $14 \%$ among university graduates to nearby autonomous regions or Madrid. It should be considered that keeping a $14 \%$ exit rate for the whole series would mean entering a bias in favour of university graduate mobility, which should be higher as we would get closer to the beginning of the series, given that mobility rates were lower at that time (Alcaide 2007). This is meant to avoid any doubt on a conservative treatment of university graduate mobility. The model to estimate now would be:

$\Delta \ln (G D P / L)_{i . t}=\alpha_{1} \Delta \ln (e s)_{i . t-n}+\alpha_{2} \Delta \ln (e s)_{f, t-n}+\alpha_{3} X_{i, t-n}+\alpha_{4} \Delta \ln Z_{i, t-n}+\alpha_{5} \Delta \operatorname{lnu}_{i . t}+\varepsilon_{i . t}$

\footnotetext{
${ }^{4}$ Moran Index values for econometric estimate variables stated the existence of a very low spatial autocorrelation, thus supporting the validity of this assumption of the behaviour of workers who graduated from university.
} 
where $i$ refers to the Autonomous Region, $\Delta \ln (G D P / L)_{i . t}$ is the interannual variation rate of GDP per capita logarithm in year $t, \Delta \ln (e s)_{f, t-n}$ is the interannual variation rate of the logarithm referring to the average number of enrolled students in neighbouring autonomous regions or Madrid for the period $t-n$, being $\varepsilon$ the error term.

\subsection{SAMPLE CHECKS: FIELDS OF KNOWLEDGE.}

Research papers normally estimating the impact of higher education on the economic growth do not take into account the composition effect. This means that the same effect is assigned to the different fields of knowledge workers can be educated in. The information provided by the Ministry of Universities allows distinguishing between those enrolled according to five fields of knowledge: Social and legal Sciences; Engineering and Architecture; Arts and Humanities; Health Sciences; and Sciences. This breakdown will mean a new contribution by making it possible to identify the potential impact of the type of university education on regional growth. For this reason, the model to be estimated now is:

$$
\Delta \ln (G D P / L)_{i . t}=\alpha_{1} \Delta \ln (e s)_{i . j, t-n}+\alpha_{2} X_{i, t-n}+\alpha_{3} \Delta \ln Z_{i, t-n}+\alpha_{3} \Delta \ln u_{i . t}+\varepsilon_{i . t}(6)
$$

where $i$ refers to the Autonomous Region, $\Delta \ln (G D P / L)_{i . t}$ is the interannual variation rate of GDP per capita logarithm in year $t, \Delta \ln (e s)_{i . j, t-n}$ is the interannual variation rate of the logarithm referring to the number of enrolled students in the field of knowledge $j$ in the period $t-n$, being $\varepsilon$ the error term.

\section{ESTIMATE RESULTS}

\subsection{MAIN RESULTS}

Once the 8-year time lag has been established in order to include the impact of enrolment growth, we have proceeded to estimate those five models in order to see if the effect of enrolments can be altered by including controls that will allow us to better identify the socioeconomic situation of each Autonomous Region. All models have been estimated using fixed effects in order to control for the unobservable features of the Autonomous Regions that remain unchanged along time. A robust error estimate has been specified to control for the potential existence of heteroscedasticity (Table 1). 
Table 1. Panel data estimate (fixed effects). Dependent variable: growth rate of the GDP per capita logarithm.

\begin{tabular}{|c|c|c|c|c|c|c|}
\hline & & jarithm. & & & & \\
\hline & Model 1 & Model 2 & Model 3 & Model 4 & Model 5 & \\
\hline Constant & 0.002 & 0.005 & 0.006 & 0.004 & 0.004 & * \\
\hline & $(0.0001)$ & $(0.001)$ & $(0.002)$ & $(0.001)$ & $(0.001)$ & \\
\hline Lagged growth of enrolments & 0.035 & 0.019 & 0.020 & 0.014 & 0.012 & * \\
\hline & $(0.019)$ & $(0.008)$ & $(0.008)$ & $(0.003)$ & $(0.003)$ & \\
\hline Lagged population & & 0.001 & 0.001 & 0.001 & 0.001 & \\
\hline & & $(0.0001)$ & $(0.0001)$ & $(0.0001)$ & $(0.0001)$ & \\
\hline Lagged GDP per capita & & -0.001 & -0.001 & -0.001 & -0.001 & * \\
\hline & & $(0.0001)$ & $(0.0001)$ & $(0.0001)$ & $(0.0001)$ & \\
\hline $\begin{array}{l}\text { Lagged percentage of population with } \\
\text { university studies }\end{array}$ & & & 0.011 & -0.013 & -0.002 & \\
\hline & & & $(0.010)$ & (0.005) & $(0.007)$ & \\
\hline Lagged unemployment rate growth & & & & 0.018 & 0.024 & * \\
\hline & & & & $(0.004)$ & $(0.003)$ & \\
\hline Unemployment rate growth & & & & -0.095 & -0.097 & * \\
\hline & & & & $(0.008)$ & $(0.008)$ & \\
\hline Lagged population growth & & & & & -0.542 & * \\
\hline & & & & & (0.096) & \\
\hline $\mathrm{R}^{2}$ within & 0.06 & 0.23 & 0.23 & 0.60 & 0.61 & \\
\hline$R^{2}$ between & 0.08 & 0.07 & 0.11 & 0.05 & 0.30 & \\
\hline $\mathrm{R}^{2}$ overall & 0.05 & 0.06 & 0.05 & 0.49 & 0.49 & \\
\hline No observations & 391 & 391 & 391 & 391 & 391 & \\
\hline
\end{tabular}

Note: * Significance at $5 \%$.

We may conclude that the variable that gathers enrolments shows high robustness, defined as a relationship that remains significant and of the same sign when including different sets of other regressors, or using slightly different data, samples or methodologies (Sianesi and Van Reenen 2003). In Model 5, we can see that a 10\% increase in the number of higher education students means $0.12 \%$ increase in GDP per capita. On the other hand, model shows greater $\mathrm{R}^{2}$ (intra groups, between groups and for the whole dataset).

Finally, following Valero and Van Reenen (2019), the effect caused by the increase in highquality human capital is expected to generate long-lasting effects on economic growth, due to the human capital accumulation effect that means including successive cohorts of university students to the labour market. But measuring this effect is limited by the fact that extending the analysis period also increases the number of variables affecting economic growth, whose information is not always available. Anyway, Table A1 of the Appendix shows different distributed lag structures, and states that, in general, 8-year lag is a reasonable summary of the data. 


\subsection{HETEROGENEITY}

Table 2 shows Model 5 results for the three groups of Autonomous Regions ${ }^{5}$.

Table 2. Panel data estimate (fixed effects). Dependent variable: growth rate of GDP per capita logarithm. Autonomous Regions grouped according to GDP per capita.

\section{Group 1 Group 2 Group 3}

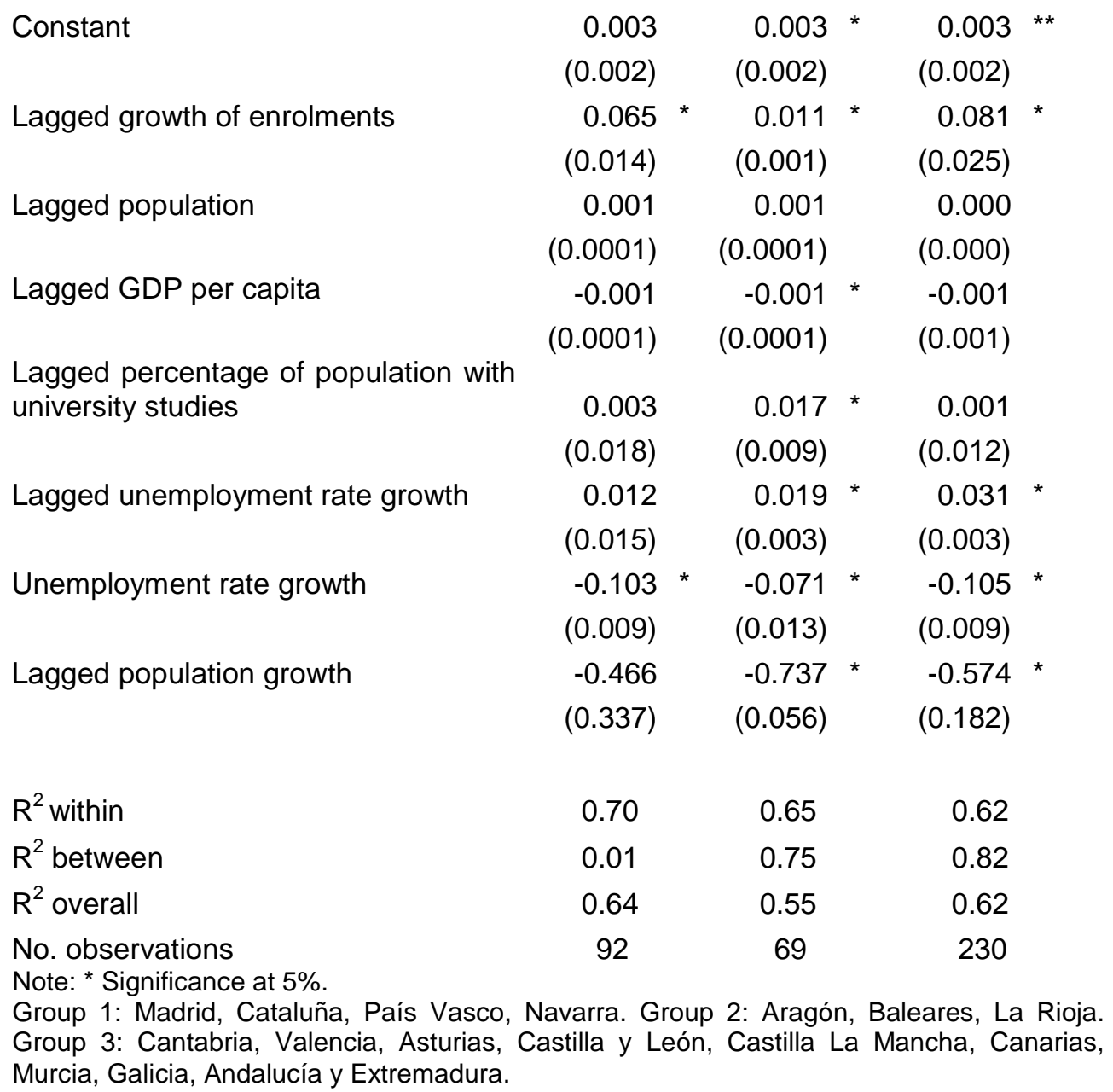

Results indicate a significant enrolment growth effect in all groups, which is greater in the case of the poorest regions

(0.081) than the richest ones (0.065), or even higher than the national average one $(0.012)$. These results seem to indicate that university education becomes an efficient tool for social cohesion as it contributes to reduce the economic gap among regions. This outcome is opposed to that obtained by Di Liberto (2008), who split Italy into two regions (the rich North-Centre, the poor South), as he did not detect this effect on Italian higher education, while he did in primary education.

\footnotetext{
${ }^{5}$ Model 1 to 4 estimates are available to the reader.
} 


\subsection{SPILLOVER EFFECTS}

Table 3 shows that the variable gathering the average growth of enrolments in neighbouring Autonomous Regions or Madrid turns out to be only significant in Models 1, 2 and 3.

Table 3. Panel data estimate (fixed effects). Dependent variable: growth rate of the GDP per capita logarithm. The neighbouring effect of enrolment growth is included.

\section{Model $1 \quad$ Model $2 \quad$ Model $3 \quad$ Model $4 \quad$ Model 5}

\begin{tabular}{|c|c|c|c|c|c|c|}
\hline Constant & $\begin{array}{r}0.001 * \\
(0.0001)\end{array}$ & $\begin{array}{r}0.004 * \\
(0.001)\end{array}$ & $\begin{array}{r}0.006 \\
(0.002)\end{array}$ & * & $\begin{array}{r}0.004 \\
(0.001)\end{array}$ & $\begin{array}{r}0.003 * \\
(0.001)\end{array}$ \\
\hline Lagged growth of enrolments & $\begin{array}{r}0.029 * \\
(0.013)\end{array}$ & $\begin{array}{rl}0.020 & * \\
(0.008)\end{array}$ & $\begin{array}{r}0.021 \\
(0.008)\end{array}$ & * & $\begin{array}{r}0.014 \\
(0.003)\end{array}$ & $\begin{array}{l}0.013 * \\
(0.00)\end{array}$ \\
\hline $\begin{array}{l}\text { Average lagged growth of enrolments } \\
\text { in neighbouring Autonomous Regions }\end{array}$ & $\begin{array}{r}0.075 * \\
(0.020)\end{array}$ & $\begin{array}{r}0.043 * \\
(0.012)\end{array}$ & $\begin{array}{r}0.046 \\
(0.013)\end{array}$ & * & $\begin{array}{r}0.009 \\
(0.006)\end{array}$ & $\begin{array}{r}0.012 \\
(0.008)\end{array}$ \\
\hline Lagged population & & $\begin{array}{r}0.001 \\
(0.0001)\end{array}$ & $\begin{array}{r}0.001 \\
(0.0001)\end{array}$ & & $\begin{array}{r}0.001 \\
(0.0001)\end{array}$ & $\begin{array}{r}0.001 \\
(0.0001)\end{array}$ \\
\hline Lagged GDP per capita & & $\begin{array}{r}-0.001 * \\
(0.0001)\end{array}$ & $\begin{array}{r}-0.001 \\
(0.0001)\end{array}$ & * & $\begin{array}{r}-0.001 \\
(0.0001)\end{array}$ & $\begin{array}{r}-0.001 \\
(0.0001)\end{array}$ \\
\hline $\begin{array}{l}\text { Lagged percentage of population with } \\
\text { university studies }\end{array}$ & & & $\begin{array}{r}0.019 \\
(0.009)\end{array}$ & * & $\begin{array}{r}-0.017 \\
(0.005)\end{array}$ & $\begin{array}{r}0.002 \\
(0.007)\end{array}$ \\
\hline Lagged unemployment rate growth & & & & & $\begin{array}{r}0.017 \\
(0.004)\end{array}$ & $\begin{array}{r}0.023 * \\
(0.003)\end{array}$ \\
\hline Unemployment rate growth & & & & & $\begin{array}{r}-0.094 \\
(0.008)\end{array}$ & $\begin{array}{l}-0.095 * \\
(0.008)\end{array}$ \\
\hline Lagged population growth & & & & & & $\begin{array}{l}-0.559 * \\
(0.096)\end{array}$ \\
\hline $\mathrm{R}^{2}$ within & 0.18 & 0.26 & 0.26 & & 0.60 & 0.62 \\
\hline $\mathrm{R}^{2}$ between & 0.04 & 0.07 & 0.18 & & 0.06 & 0.40 \\
\hline $\mathrm{R}^{2}$ overall & 0.17 & 0.07 & 0.11 & & 0.52 & 0.53 \\
\hline No. observations & 391 & 391 & 391 & & 391 & 391 \\
\hline
\end{tabular}

This result seems to be in line with the little likelihood of Spanish labour force to move within the national territory. Besides, it is important to point out that including this variable does not remarkably vary the effect of the enrolment growth in each Autonomous Region, thus underpinning the idea of how little influence those influxes of graduates from other Autonomous Regions have on regional growth.

\subsection{FIELDS OF KNOWLEDGE.}

The results (Table 4) confirm the importance of the composition effect, as, in general, field of knowledge variables exercise a significant effect in all models. Taking the Arts and Humanities field as reference, Model 5 results show that the growth of enrolled students in the field of Health Science does not affect the regional economic growth, but it indeed has an impact on the rest of models. The fields of Science and Social Science exercises a similar positive effect on GDP per capita growth (a 10\% increase in students enrolled in Science increases GDP per capita by $0.21 \%$, whereas in case of Social Sciences the growth is $0.16 \%$ ), and higher that the one observed for the whole analysis of all fields (0.12\%). Finally, enrolments in Engineering and 
Architecture have a positive impact in all models, while its magnitude is highly reduced (in Model 5, a 10\% increase in students enrolled in this field, increases GDP per capita by $0.08 \%$ ).

Table 4. Panel data estimate (fixed effects). Dependent variable: growth rate of the GDP per capita logarithm. The effect of enrolment growth by field of knowledge.

Model 1 Model $2 \quad$ Model $3 \quad$ Model $4 \quad$ Model 5

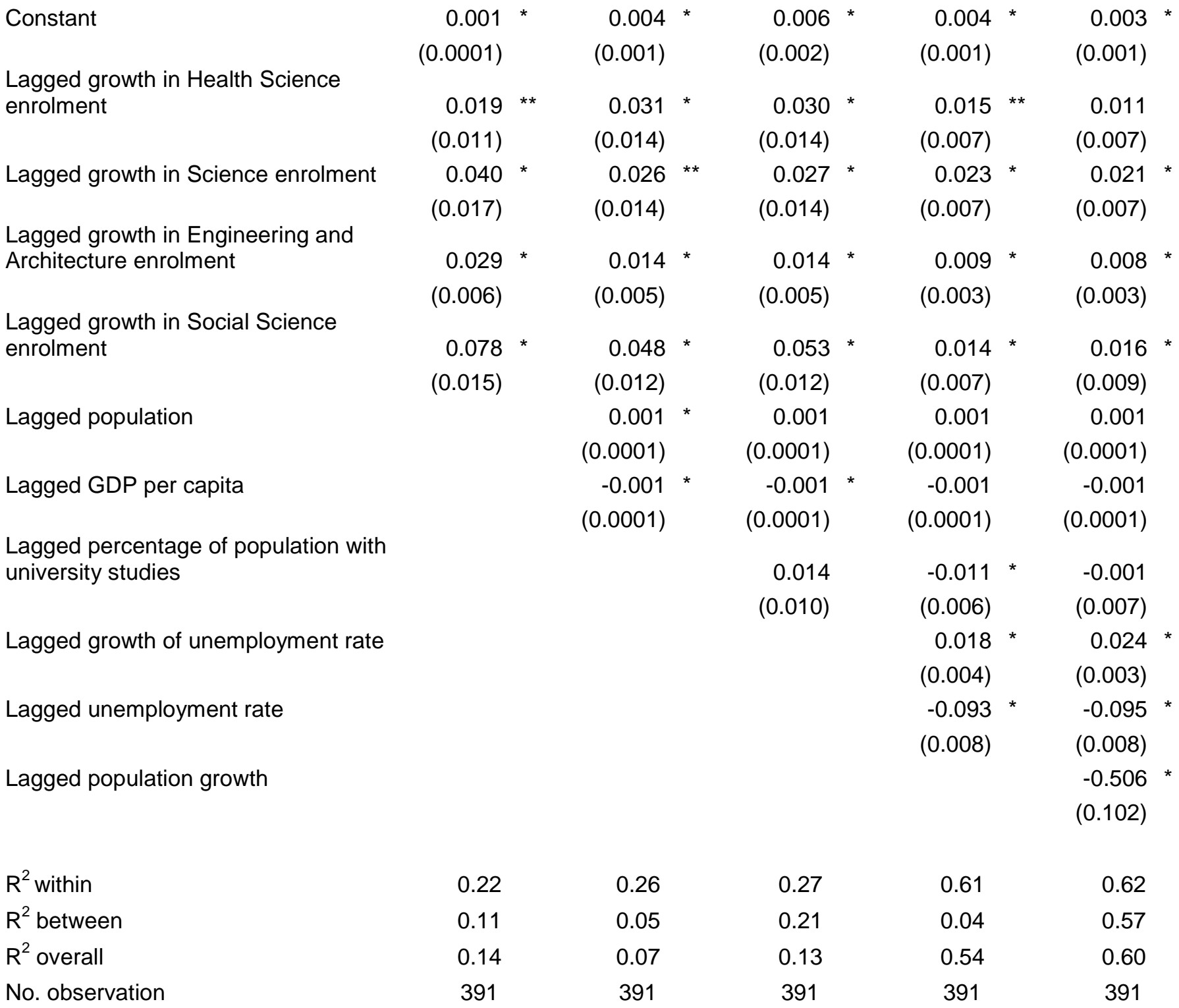

Note: * Significance at $5 \%{ }^{* *}$ Significance at $10 \%$. Field of knowledge of reference: Arts and Humanities

The low impact of Engineering and Architecture studies on regional growth seems initially surprising, and may be for two reasons mainly. First of all, it may be due to the high dropout rate of students compared to other fields of knowledge, according to the data provided by the Ministry of Universities. Secondly, it may be due to its decreasing relevance in relation to the whole university offer due to the decreasing number of enrolments since 2002. In relation to the latter, the Human Capital Theory can be used as a possible explanation. This theory says that university students' choice of a given field of knowledge depends on the expected net return: on the investment side, the necessary intellectual effort to pass those studies seems to be more high each time, given the low level of maths knowledge of students enrolling Spanish universities, as it has been revealed by the PISA report since 2002; as far as return is 
concerned, given that the Spanish productive structure is based on small and medium enterprises, it does not seem to be able to offer wages that compensate for the demanding intellectual effort, which will work for making this field of knowledge less attractive.

\section{CONCLUSIONS}

This research provides empirical evidence on the effect that higher education has on the regional economic growth. For this reason, we have proceeded to analyse a panel of data with information corresponding to Spanish Autonomous Regions from 1985 to 2016 . By defining an 8-year time-lag as the variable measuring student enrolment growth, the results indicate that first of all, as an average, a 10\% increase in the number of enrolled students generates an increase of regional GDP per capita of $0.12 \%$. Besides, this result is robust as the variable effect remains significant and of the same sign when including different sets of other regressors. This outcome is in line with the one reached by Valero and Van Reenen (2019), who obtained a higher effect $(0.4 \%)$, taking, though, a heterogeneous base of regions and using the number of universities as higher education level proxy.

The outcomes of this research seem to support European higher education policy. According to the European Commission, higher education institutions (HEIs) are crucial partners in delivering the European Union strategy to drive forward and maintain sustainable economic growth. The ET 2020 PLA (seminars organised within the framework of the Open Method of Coordination for the Working Group on the Modernisation of Higher Education) on "Higher Education Institutions as centres of regional development and innovation" confirm the continuing policy interest and focus on higher education as centres of regional development and innovation. European policy supports HEls' regional role. The Agenda for the Modernisation of Higher Education (European Commission 2017) emphasises the regional knowledge triangle, combining research, education and innovation. In this context, the "triple helix" model (Leydesdorff and Etzkowitz, 1996) of regional collaboration and innovation (government-business-HEIs) must continue to dominate over a more broad-based engagement that includes the local population and civil society ("quadruple helix").

In order to boost HEls impact, the Europe 2020 strategy has set a target according to which $40 \%$ of young Europeans should have a higher education qualification by 2020 (Poelman and Dijkstra, 2018). The regional spread of higher education institutions is an important dimension of the EU's agenda to the goals of the European 2020 strategy (European Commission, 2020). On the one hand, a broader geographical coverage lowers costs and barriers for student's access to higher education. Denzler and Wolter (2010), validated the well-documented influence of the distance between home and university in choosing university studies, and how an uneven distribution of opportunities to access university may impact on the use of human capital to its full potential. Therefore, a geographical diffusion of university studies offer is expected to contribute to building 'more inclusive' higher education systems, since students from lower social classes are more penalized as they need to move to another region for tertiary education, which generates substantial commuting and accommodation costs (Eurostudent 2019). On the other hand, having universities geographically close is a major advantage for firms and social actors that make use of research inputs, as these partnerships provide direct knowledge flows. Therefore, the presence of one or more HEls in a region is an asset that helps foster knowledge flows along education, research and business in order to promote a balanced development among European regions. Spain has clearly led its university polity in this direction, thus promoting university presence in all Autonomous Regions. As a consequence, universities are currently found in all Spanish provinces (NUTS3), either its headquarters or satellite campuses. However, there are two main questions coming from this dispersal policy, which must lead to policy makers' reflection. First of all, to what extent is this policy is profitable for the society? Public funding for higher education is under increasing scrutiny, and there are growing demands for HEls to demonstrate their value, contribution and benefit to the economy and society (Kehm, 2007). The issue of an increasing public expenditure on HEls comes from the fact that, given that higher education investment promotes economic growth, it could be concluded that it is better for the Autonomous Regions to keep a higher number of university at all times. In fact, this seems to be the grounds presented many regional leaders as a strategy to obtain votes from families who would have to spend an important percentage of their income to finance university studies away from home. However, the geographical diffusion of higher education also entails the risk of generating additional costs by diluting scarce resources across a too wide range of institutions and localisations (ETER, 2019). Therefore, this continuous university 
expansion policy must undergo a deep profitability analysis so as not to put HEls sustainability into danger. In the second place, HEls development at regional level has the immediate effect that young people do not leave the region to carry on with their studies, and probably, due to boosting that university-local firm relationship, it will also promote graduates to remain in their regions. Likewise, competence among regions in terms of both the size of university offer and its diversity and quality, discourage students' mobility around the national territory, as it will cut opportunity costs. For example, Faggian et al. (2007) found that Scottish and Welsh students who managed to enrol a high-quality university in their home region were less likely to move away for higher education purposes. These behaviour hypothesis seems to be like this in Spain, and may cause an undesirable effect when considering that the geographical mobility of people encourages a more balanced economic and social development.

Future research should evaluate the effect on student mobility that the increase in the variety of bachelor and master degrees can generate. That is, not only the geographical expansion of the University can simplify the movement of students between different geographical areas, but also the increase in the variety of content of the degrees by adapting the offer of University studies to the specific needs of the labour market of each region.

\section{Acknowledgments:}

This paper has been funded by the Ministry of Science and Innovation (Project number ECO2017-86402-C2-1-R), and by the University of Oviedo (Project number PAPI-20-GR-20140076). I would like to thank three anonymous referees, as well as my colleagues Antonio Alvarez Pinilla and David Roibás.

This article has been published in Regional Studies: DOI:10.1080/00343404.2021.1901870 


\section{References}

Aghion, P., Meghir, C., \& Vandenbussche, J. (2006). Growth, distance to frontier and composition of human capital. Journal of Economic Growth, 11(2), 97-127

Alcaide, I. (2007). Evolución de la población española en el siglo XX, por provincias y comunidades autónomas. Volumen I. Fundación BBVA. Bilbao

Bentolila, S. (2001). Las Migraciones Interiores en España. FEDEA Working Paper 2001-07

Bonaccorsi, A., Biancardi, D., Sánchez-Barrioluengo, M., \& Biagi, F. (2019). Study on higher education institutions and local development. Joint Research Centre. Publications Office of the European Union. Luxembourg

Canal, J.F., \& Rodríguez, C. (2019). University education and transition into the labour market during the financial crisis. Spanish evidence. Quality in Higher Education, 25 (2), 155-170

De La Fuente, A. (2017). Series largas de algunos agregados económicos y demográficos regionales: Actualización de RegData hasta 2016. FEDEA Working Paper 2017/26

De Meulemeestert, J.L., \& Rochat, D. (1995). A causality analysis of the link between higher education and economic development. Economies of Education Review, 14(4), 351-361

Denzler, S., \& Wolter, S. (2010). Distance to University and study decisions: a research note. Swiss Political Science Review, 16 (4), 807-09

Di Liberto, A. (2008) Education and Italian regional development. Economics of Education Review, 27, 94-107

Drucker, J., \& Goldstein, H. (2007). Assessing the regional economic development impacts of universities: a review of current approaches. International Regional Science Review, 30(1), 2046

European Tertiary Education Register (ETER) (2019). The regional structure of European Higher Education. Analytical Report 4/2019. European Commission. Brusels.

European Commission (2017). Communication from the Commission to the European Parliament, the Council, the European Economic and Social Committee and the Committee of Regions on a renewed EU agenda for higher education. COM/2017/0247 final. Brussels.

European Commission (2020). Communication from the Commission. Europe 2020. A strategy for smart, sustainable and inclusive growth. Brussels.

Eurostudent (2019). Eurostudent VI. Overview and selected findings. Social and economic conditions. of students in Europe. Available at www.eurostudent.eu. 
Faggian, A., McCann, P. \& Sheppard, S. (2007). Human capital, higher education and graduate migration: an analysis of Scottish and Welsh students. Urban Studies, 44(13), 2511-2528

Gennaioli, N., La Porta, R., Lopez-de-Silanes, F., \& Shleifer, A. (2013). Human capital and regional development. The Quarterly Journal of Economics, 128 (1), 105-164

Gennaioli, N., La Porta, R., Lopez-de-Silanes, F., \& Shleifer, A. (2014). Growth in regions. Journal of Economic Growth, 19, 259-309

Hanushek, E., \& Wößmann, L. (2010). Education and Economic Growth. In Peterson P, Baker E, McGaw B (ed.) International Encyclopedia of Education. Elsevier, Oxford, 2, 245-252

Kehm, B.M. (2007). Quo vadis doctoral education? New European approaches in the context of global changes. European Journal of Education, 42, 307-319.

Kivinen, O., \& Nurmi, J. (2014). Labour market relevance of European university education. From enrolment to professional employment in 12 countries. European Journal of Education, 49 (4), 558-74

Leydesdorff, L.\& Etzkowitz, H. (1996). Emergence of a triple hélix of university-ndustrygovernment relations. Science and Public Policy, 23(5), 279-286.

Lucas, R.E. (1988). On the mechanics of economic development. Journal of Monetary Economics, 22, 3-42.

Poelman, H., \& Dijkstra, L. (2018). Access to universities in the EU: a regional and territorial analysis. Regional Focus 1/2018.

Ródenas, C., \& Martí, M. (2005). El nuevo mapa de las migraciones interiores en España: los cambios en el patrón de los sesenta. Investigaciones Regionales, 6, 21-39

Salas, M. (2007). The transition from higher education to employment in Europe: the analysis of the time to obtain the first job. Higher Education, 54, 333-360

Sianesi, B., \& Van Reenen, J. (2003) The returns to education: macroeconomics. Journal of Economic Surveys, 17(2), 157-200

Valero, A., \& Van Reenen, J. (2019). The economic impact of universities: Evidence from across the globe. Economics of Education Review, 68, 53-67. 


\section{APPENDIX}

Table A1. Distributed lag specifications

\begin{tabular}{|c|c|c|c|c|c|c|}
\hline & $\begin{array}{c}\text { (1) } \\
\text { Coef. } \\
\text { (St. Dev.) }\end{array}$ & $\begin{array}{c}\text { (2) } \\
\text { Coef. } \\
\text { (St. Dev.) }\end{array}$ & $\begin{array}{c}\text { (3) } \\
\text { Coef. } \\
\text { (St. Dev.) }\end{array}$ & $\begin{array}{c}(\mathbf{4}) \\
\text { Coef. } \\
\text { (St. Dev.) }\end{array}$ & $\begin{array}{c}\text { (5) } \\
\text { Coef. } \\
\text { (St. Dev.) }\end{array}$ & $\begin{array}{c}(\mathbf{6}) \\
\text { Coef. } \\
\text { (St. Dev.) }\end{array}$ \\
\hline $\begin{array}{l}\text { years lagged growth of } \\
\text { trolments }\end{array}$ & 0.013 * & $0.009 *$ & $0.008 *$ & $0.007 *$ & $0.009 *$ & 0.010 \\
\hline & $(0.004)$ & $(0.002)$ & $(0.002)$ & $(0.002)$ & $(0.002)$ & $(0.002)$ \\
\hline $\begin{array}{l}\text { years lagged growth of } \\
\text { trolments }\end{array}$ & & $\begin{array}{l}-0.002 \\
(0.001)\end{array}$ & $\begin{array}{l}-0.005 * \\
(0.002)\end{array}$ & $\begin{array}{r}-0.002 \\
(0.003)\end{array}$ & $\begin{array}{r}-0.004 \\
(0.003)\end{array}$ & $\begin{array}{r}-0.001 \\
(0.003)\end{array}$ \\
\hline $\begin{array}{l}\text { years lagged growth of } \\
\text { trolments }\end{array}$ & & & $\begin{array}{l}-0.007 * \\
(0.001)\end{array}$ & $\begin{array}{r}-0.004 * \\
(0.002)\end{array}$ & $\begin{array}{r}0.003 \\
(0.003)\end{array}$ & $\begin{array}{r}0.003 \\
(0.003)\end{array}$ \\
\hline $\begin{array}{l}\text { years lagged growth of } \\
\text { rrolments }\end{array}$ & & & & $\begin{array}{r}-0.008 \\
(0.003)\end{array}$ & $\begin{array}{r}-0.006 \\
(0.003)\end{array}$ & $\begin{array}{r}-0.003 \\
(0.003)\end{array}$ \\
\hline 10 years lagged growth of enrolments & & & & & $\begin{array}{l}0.007^{* *} \\
(0.004\end{array}$ & $\begin{array}{r}0.007 \\
(0.005)\end{array}$ \\
\hline years lagged growth of enrolments & & & & & & $\begin{array}{r}0.001 \\
(0.002)\end{array}$ \\
\hline $\begin{array}{l}\text { Observations } \\
\text { te: * Significance at } 5 \% \text {; } * \text { Significanc }\end{array}$ & $\begin{array}{c}391 \\
\text { ice at } 10 \%\end{array}$ & $\begin{array}{l}391 \\
\text { e rest of }\end{array}$ & $\begin{array}{c}391 \\
\text { covariates }\end{array}$ & $\begin{array}{c}374 \\
\text { oresent in tl}\end{array}$ & $\begin{array}{l}357 \\
\text { estimates }\end{array}$ & $\begin{array}{r}340 \\
\text { e been }\end{array}$ \\
\hline
\end{tabular}

Column 1 shows GDP per capita growth rate is estimated based on 8-year lag explanatory variables of model 5; Column 2 adds 6-year lag explanatory variables; Column 3 adds 7-year lag explanatory variables; Column 4 adds 9-year lag explanatory variables; Column 5 adds 10-year lag explanatory variables; Column 6 adds 11-year lag explanatory variables. Estimate values for the variable gathering enrolment growth rate are the only ones shown for easy-reading purposes. As it can be observed in Table A1, the estimated coefficient for an 8-year lag is statistically significant for all proposed equations, while exercising a positive effect; a 6-year lag is statistically significant in equation 3 (with a negative sign); a 7-year lag is statistically significant in equations 3 and 4 (with a negative sign); a 9year lag is statistically significant in equation 4 (with a negative sign); and a 10-year one is positive and statistically significant at $10 \%$ only in equation 5 . 